\title{
Rancangan Pelayanan Logistik pada PT. XXX dengan Menggunakan Metoda Morphological Chart
}

\author{
Erika \\ Program Studi Teknik Industri, Institut Sains dan Teknologi Nasional \\ Jl. Moh. Kahfi II, Jagakarsa, Jakarta 12640, Indonesia \\ E-mail : er1k4_ye2n1@yahoo.com
}

\begin{abstract}
Abstrak
Bisnis logistik adalah bisnis yang potensinya sangat besar untuk terus berkembang di Indonesia. Saat ini pemain asing semakin agresif masuk. potensi pasar logistik di Indonesia mencapai 10 persen dari produk domestik bruto (PDB) nasional per tahunnya. Kondisi itu mengundang minat perusahaan asing untuk masuk ke bisnis logistik di Indonesia. PT. XXX merupakan salah satu perusahaan nasional yang bergerak di bisnis logistik. Pelayanan logistik yang diterapkan oleh PT. XXX selama ini sebagian besar masih secara manual, sehingga kurang dapat menyelesaikan masalah, terutama mengenai ketidak tepatan waktu barang diterima oleh konsumen dan juga adanya kesulitan dalam melacak posisi barang. Pada penelitian ini metode perancangan logistik yang dipakai adalah menggunakan metoda morphological chart. Dari metode ini didapatkan beberapa alternatif rancangan. Dari beberapa alternatif tersebut dipilih satu rancangan yang memiliki bobot paling tinggi, yaitu alternatif untuk menerapkan sistem pelayanan logistik terpadu berbasis komputer/website. Dengan sistem operasi yang hampir semuanya menggunakan sistem informasi yang terintegrasi, maka proses pelacakan barang dapat dilakukan secara langsung melalui sistem komputer yang terintegrasi, dan ini memungkinkan untuk mengetahui posisi barang secara realtime dan dapat diakses secara langsung oleh konsumen melalui website.
\end{abstract}

Kata Kunci : pelayanan logistik, morphological chart, komputer/website

\begin{abstract}
Logistic business sector has a great potential to evolve sustainably in Indonesia. Recently, large numbers of logistic foreign enterprises aggresively intend to provide logistic service in Indonesia. Logistic market of Indonesia annually has reached $10 \%$ of National Product Domestic Bruto. The condition has attracted foreign company to invest in logistic business sector in Indonesia. PT. XXX is one of national logistic servive company. Logistic service which is carried out by PT. XXX mostly apply manual system, therefore several issues regarding delay and difficulty to detect the position of goods. Concerning design logistic method, this research i tends to apply the morphological chart method. The method comprises numbers of design alternatives. Therefore the research will select the one of design alternatives which has the most crucial point namely logistic integrated computer-based system. By using integrated information system, then goods tracing process might be able committed through integrated computer-based system, furthermore consumer will be able to trace their stuff in real time through website.
\end{abstract}

Keywords : logistic service, morphological chart, computer/website

\section{Pendahuluan}

Sektor logistik merupakan urat nadi perdagangan dalam negeri dan internasional. Tanpa kelancaran bekerjanya sektor logistik, proses produksi akan terganggu. Makin meningkatnya volume perdagangan barang, baik perdagangan domestik maupun internasional, membuat bisnis logistik makin diminati.

PT. XXX sebagai salah satu perusahaan nasional yang bergerak di bisnis logistik, selalu berusaha untuk meningkatkan daya saing bisnisnya sehingga suatu saat diharapkan dapat menjadi market leader di bisnis ini.

Dalam upayanya meningkatkan daya saing bisnis terutama pada bisnis logistik yang penuh dengan persaingan dan semakin maraknya pemain asing di bisnis ini dan di tambah belum adanya regulasi yang jelas pada sektor ini, banyak permasalahan-permasalahan yang dihadapi oleh PT. Internusa Hasta Buana. Oleh karena itu, perlu dilakukan analisis terhadap permasalahan-permasalahan terkait sistem pelayanan logistik yang sekarang telah 
dijalankan oleh PT. Internusa Hasta Buana untuk kemudian dicarikan solusinya sehingga daya saing perusahaan tetap tinggi dan dapat memenangkan persaingan bisnis yang sangat kompetitif ini.

\section{Methodologi}

\section{A. Identifikasi Peluang}

Untuk mengidentifikasi peluang, kita perlu mendefinisikan pasar. Ketentuan pasar adalah ukuran yang harus kita gunakan dalam mengidentifikasikan peluang. Identifikasi peluang bisa didasarkan pada jasa yang sudah ada, kebutuhan konsumen, kependudukan, perilaku terhadap produk atau kriteria lain.

Aspek penting lainnya dari definisi pasar adalah berkenaan dengan meneliti hubungan jasa baru dengan jasa yang sudah ada dari suatu perusahaan. Jika jasa baru memiliki pasar yang sama dengan jasa yang sudah ada, maka kanibalisasi bisa terjadi.

Dari peta posisi di atas dapat di lihat bahwa dari faktor market attractiveness, perusahaan berada pada posisi High yang berarti bahwa produk berada pada pasar yang memiliki tingkat persaingan tinggi. Sedangkan dari faktor oganization's capabilities perusahaan berada pada posisi Medium yang menunjukkan bahwa erusahaan memiliki kemampuan menengah untuk berada dalam pasar.

\section{B. Tujuan Rancangan}

Metode objectives tree menawarkan format yang jelas dan berguna untuk menyampaikan tujuan. Objectives tree memperlihatkan tujuan dan cara mencapainya, serta menunjukkan dalam bentuk diagram hubungan satu sama lain dari bermacam tujuan yang berbeda, dan pola hierarki dari tujuan dan sub tujuan. Objectives tree membantu memaparkan tujuan secara jelas dan meraih kesepakatan antar klien, manajer, dan anggota dari tim desainer.

\section{Penetapan Fungsi}

Metode untuk melakukan penetapan fungsi ini adalah dengan melakukan analisis fungsi yang terdiri dari:

1. Menyatakan semua fungsi dalam bentuk input dan output.

2. Menguraikan fungsi keseluruhan ke dalam bentuk sub fungsi-sub fungsi utama.

3. Menggambarkan hubungan antara sub fungsi-sub fungsi dalam bentuk block diagram.

4. Menggambarkan batasan dari sistem yang akan dianalisis.

5. Mencari komponen-komponen yang sesuai dari setiap sub fungsi.

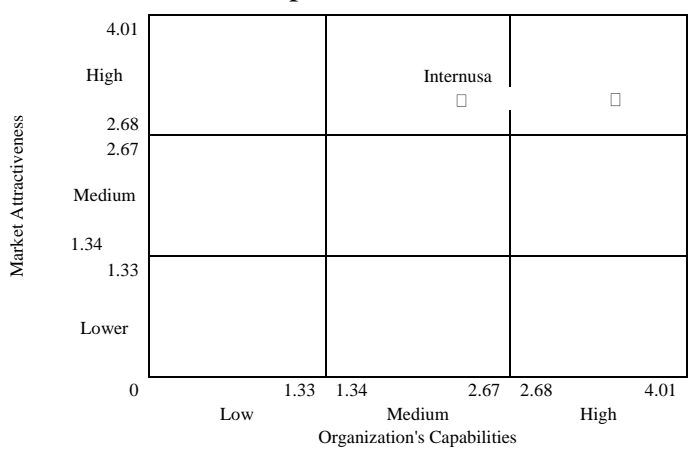

Gambar 1. Peta Posisi Produk Dari Sisi Market Attractiveness vs Organization's Capabilities

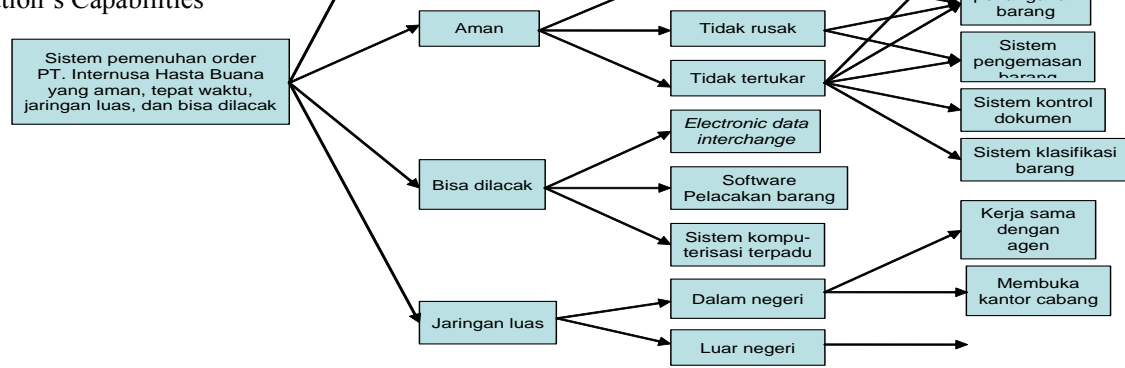

Gambar 2. Sistem nyata (real system) dari PT. Internusa Hasta Buana 


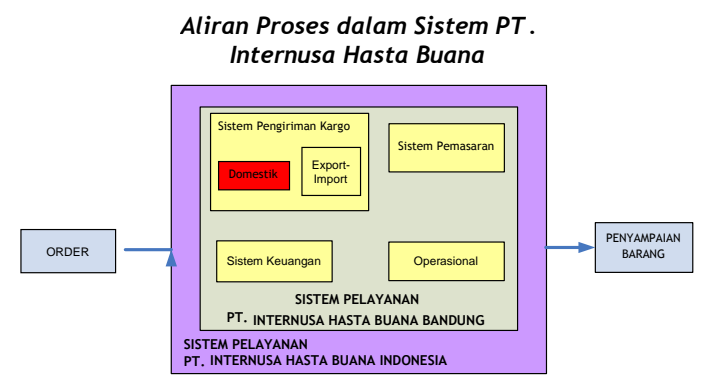

Gambar 3. Aliran Proses dalam Sistem PT. Internusa Hasta Buana

System pelayanan PT. Internusa Hasta Buana Bandung merupakan bagian dari system pelayanan PT. Internusa Hasta Buana Indonesia yang berkedudukan di Jakarta. Sistem pelayanan PT. Internusa Hasta Buana Bandung terdiri dari sistem pemasaran, sistem keuangan, sistem pengiriman kargo dan operasional. Fokus pembahasan dikhususkan hanya untuk proses pengiriman kargo untuk pasar domestik karena sistem inilah yang merupakan core dari sistem pelayanan PT. Internusa Hasta Buana sedangkan untuk pasar export-import sistem pelayanan dilakukan oleh PT. FPS Indonesia.
Selanjutnya digambarkan sistem pengiriman kargo dari PT. Internusa Hasta Buana.

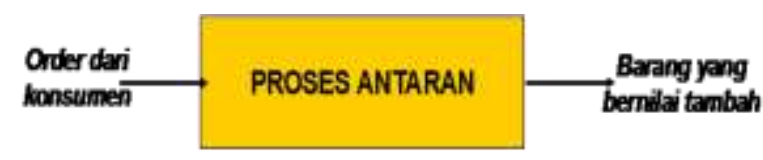

Gambar 4. Black-Box Delivery Service PT. Internusa Hasta Buana

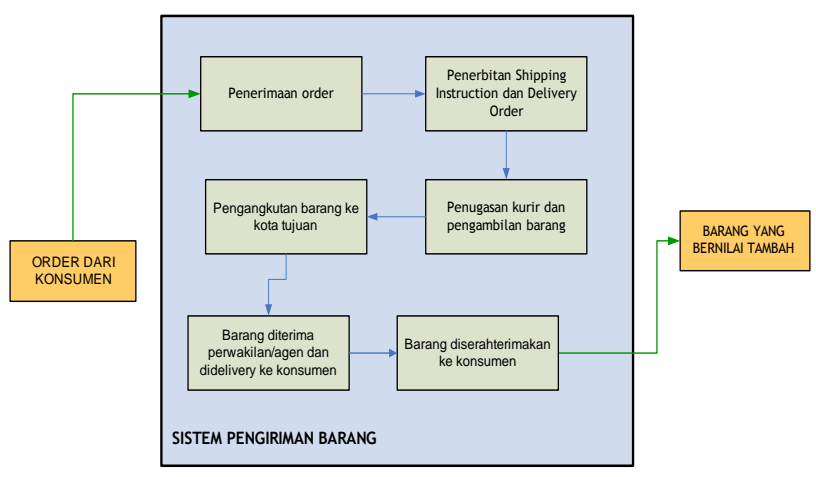

Gambar 5. Analisis fungsi sistem pengiriman kargo domestik PT. Internusa Hasta Buana

\section{Spesifikasi Rancangan}

Tabel 1.

Penetapan komponen-komponen dari setiap sub fungsi system pengiriman kargo PT. Internusa Hasta Buana

\begin{tabular}{|c|c|c|}
\hline & Sub-functions & Components \\
\hline 1. & Penerimaan order & $\begin{array}{ll}\text { a. } & \text { Petugas customer service } \\
\text { b. } & \text { Shipping Instruction dan Pick-up request form } \\
\text { c. } & \text { Alat komunikasi: telephon dan internet } \\
\text { d. } & \text { Sistem informasi } \\
\text { e. } & \text { Ruangan pelayanan }\end{array}$ \\
\hline 2. & Penugasan kurir & $\begin{array}{ll}\text { a. } & \text { Pick-up request form } \\
\text { b. } & \text { Sistem informasi } \\
\text { c. } & \text { Alat komunikasi: telephon }\end{array}$ \\
\hline 3. & Pengambilan barang & $\begin{array}{ll}\text { a. } & \text { Kurir } \\
\text { b. } & \text { Barang yang akan dikirim } \\
\text { c. } & \text { Alat komunikasi: handphone } \\
\text { d. } & \text { Sistem informasi } \\
\text { e. } & \text { Alat transportasi: motor, van, dan truk } \\
\text { f. } & \text { Way bill } \\
\text { g. } & \text { Atribut pengepakan }\end{array}$ \\
\hline 4. & Pengangkutan barang ke kota tujuan & $\begin{array}{ll}\text { a. } & \text { Operator } \\
\text { b. } & \text { Barang yang akan dikirim } \\
\text { c. } & \text { Alat transportasi: truk dan kapal pengangkut } \\
\text { d. } & \text { Alat komunikasi } \\
\text { e. } & \text { Sistem informasi }\end{array}$ \\
\hline 5 . & Penyerahan barang ke konsumen & $\begin{array}{ll}\text { a. } & \text { Perwakilan/agen } \\
\text { b. } & \text { Barang yang akan dikirim } \\
\text { c. } & \text { Sistem informasi }\end{array}$ \\
\hline
\end{tabular}


Tabel 2.

Performance spesification untuk system pengiriman barang PT. Internusa Hasta Buana

$\begin{array}{ll}\text { Objective Criteria } & \text { Cre }\end{array}$

1. Aman

Tidak Hilang : Barang yang akan dikirim dijamin tidak akan hilang karena proses pemenuhan order telah melalui sistem pengawasan barang yang ketat, sistem pemberian label yang cermat dan sistem penanganan barang yang tepat.

Tidak Rusak : Barang yang dikirim diperlakukan melalui sistem penanganan barang dan sistem pengemasan barang yang tepat, cermat dan hati-hati sehingga barang yang akan dikirim tidak akan rusak.

Tidak tertukar : Dilakukan sistem klasifikasi barang dan sistem kontrol dokumen yang akurat sehingga barang yang dikirim tidak akan tertukar dengan barang yang lain.

2. Tepat Waktu Waktu pengiriman barang hingga sampai ke pelanggan harus sesuai dengan janji perusahaan kepada konsumen, karena itu perlu didukung oleh sistem penugasan, sistem informasi dan sistem routing yang dilakukan.

3. Jaringan luas PT. Internusa Hasta Buana memiliki jaringan yang luas karena membuka kantor cabang dan menjalin kerja sama dengan agen di berbagai daerah dan perusahaan logistik internasional.

4. Bisa dilacak Untuk meningkatkan pelayanan kepada konsumen, perusahaan memiliki fasilitas untuk melacak keberadaan barang dengan sistem komputerisasi terpadu, software pelacakan barang dan Electronic Data Interchange.

Tabel 3.

Sistem Pelayanan Yang Berlaku Saat ini

\begin{tabular}{|c|c|c|}
\hline Fungsi & \multicolumn{2}{|c|}{ Altematif Solusi } \\
\hline \multicolumn{3}{|l|}{ 1. Penerimazn Order } \\
\hline Petugas customer service & Marketing/sales & Officer, resepsionis \\
\hline Yedia penerimaan order & Mejà pelaranan & Telepon, frximili, internet, meja pela jaman \\
\hline Bukti penerimsin order & Log book onder & Forn lhasus, conputerized \\
\hline Sisten informasi & Log book & Forn lhasus, conputerized \\
\hline Rumpan pelaryanan & Resepsionist & Ruangan tersendiri \\
\hline \multicolumn{3}{|l|}{ 2. Penugasan karir } \\
\hline Operator & Marketing/sales & Officer, resepsionis \\
\hline Alat komunikasi penugasan & Directly Order & Telepon, hp, internet \\
\hline Buksti Penugasan Kurit & Form Khusus & conputerized, wrebsilp \\
\hline \multicolumn{3}{|l|}{ 3. Pengambilan Barang } \\
\hline Operator & Officer & Marketing/sales \\
\hline Alat komunikasi pengambil & Telepon, hp & Internet \\
\hline Alat transportasi & Trailer & Mobil Box, trad \\
\hline Lokasi pengisian dan penempelan Way Bill & Di lokasi pengambilan (konsumen) & Di kantor \\
\hline \multicolumn{3}{|l|}{ 4. Pemeriksazan Barang } \\
\hline Operator & Officer: & Marketing/sales \\
\hline Metode Pemeriksaan Barang & Manzal & conputerized, websile \\
\hline \multicolumn{3}{|l|}{ 5. Pengemasan Basang } \\
\hline Proses pengepakan barang & Oleh konsumea & Oleh operator \\
\hline Sistem Laheling barang vang akan dikirim & Label khusus & Menegeunakan Barcode \\
\hline \multicolumn{3}{|l|}{ 6. Pengiriman Barang be tempat tujuan } \\
\hline Operator & Kunis & Officer \\
\hline Alat transpottasi & Trailer & Mobi1 Box, trud \\
\hline Alat Somunikasi & Telepon, hp & Internet \\
\hline Buskti penerimazn Barang oleh Konsumen & Form Khusus & conputerized, websile \\
\hline Metode pelacakan keberadaan barang & Manaal & conputerized, websile \\
\hline
\end{tabular}

SURYA TEKNIKA Vol. 1 No. 4, Juni 2016: 55 -66 
Tabel 4.

Alternatif Solusi 1

\begin{tabular}{|c|c|c|}
\hline Fungsi & \multicolumn{2}{|c|}{ Alternatif 5 olusi } \\
\hline \multicolumn{3}{|l|}{ 1. Penerimaan Order } \\
\hline Petug as customes service & Marketing/sales & Officer, resepsionis \\
\hline Media penerimaan order & Meja pelayanan & Telepon faximili, internet, meja pelayanan \\
\hline Bukti penerimaan order & Log book order & Porm khmsus, compu terized \\
\hline Sistem informasi & Log book & Porm khusus, computerized \\
\hline Ruangan pelayanan & Resepsionist & Ruangen tersendifi \\
\hline \multicolumn{3}{|l|}{ 2. Penugasan kurir } \\
\hline Operator & Marketing/sales & Officer, resepsianis \\
\hline Alat kom unikasi perusgasan & Directly Order & Telepon, hp, internet \\
\hline Bukkti Penugasan Kurit & Form khusus & computerized, websilt \\
\hline \multicolumn{3}{|l|}{ 3. Pengambilan Barang } \\
\hline Operator & Officer & Marketing/sales \\
\hline Alat komunikasi pengam bil & Telepon, hp & Internet \\
\hline Alat transportasi & Trailer & Mobil Box, truck \\
\hline Lokasi pengisian dan penempelan Way Bill & Di lokasi pengambilan (konswmen) & Di kantor \\
\hline \multicolumn{3}{|l|}{ 4. Pemeriksaan Barang } \\
\hline Operator & Officer & Marketing/sales \\
\hline Metode Pemeriksaan Barang & Manual & computerized, website \\
\hline \multicolumn{3}{|l|}{ 5. Pengemasan Barang } \\
\hline Froses pengepakan barang & Oleh kansumen & Oleh opetator \\
\hline Sistem Labeling barang yang akan dikirim & Label khusus & Mengstanakan Barcode \\
\hline \multicolumn{3}{|l|}{ 6. Pengiriman Barang ke tempat tujuan } \\
\hline Operator & Kurir & Otficer \\
\hline Alat transportasi & Trailer & Mobil Box, truck \\
\hline Alat komunikasi & Telepon, hp & Internet \\
\hline Bukti penerimean Barang oleh Konsumen & Form khuseas & computerized, websits \\
\hline Metode pelacakan keberadaan barang & Mantual & computerized, website \\
\hline
\end{tabular}

Tabel 5.

Alternatif Solusi 2

\begin{tabular}{|c|c|c|}
\hline \multirow{2}{*}{$\begin{array}{l}\text { Fungsi } \\
\text { 1. Penerimaan Order }\end{array}$} & \multicolumn{2}{|c|}{ Alternatif Solusi } \\
\hline & & \\
\hline Petugas customer service & Marketing/sales & Othicer, resepsienin \\
\hline Media penerimaan order & Mejs pelayansa & 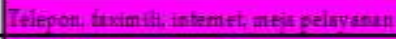 \\
\hline Bukti penerimasa onder & Log book order & Form khesus, compolentied \\
\hline Sistem informasi & Log book & Form khvest, computerised \\
\hline Ruangan pelayansn & Resepsionist & Beangan tereadiri: \\
\hline \multicolumn{3}{|l|}{ 2. Peatrgasin kurir } \\
\hline Operator & Marketing/sales & Othicer, resepsieaits \\
\hline Alat kostunikasi penugasain & Directiv 0xder & Ttiegorn, bs, intemet \\
\hline Bektti Penagasen Karir & Form khusus & computernoedi, nebsite. \\
\hline \multicolumn{3}{|l|}{ 3. Pengambilan Barang } \\
\hline Operator & Otficer & Msrketing/ssles \\
\hline Alat koununikasi pengam bil & Felepon ha & Internet \\
\hline Alat transportasi & Frader & Yobul bos trezk \\
\hline Lokasi pengisian dan penempelan Wav Bill & Dit lakasi panenebilin thonsumeni & Di kentor \\
\hline \multicolumn{3}{|l|}{ 4. Pealeriksaan Barang } \\
\hline Operator & Oitice: & Msrketing/ssles \\
\hline Metode Pemeniksaan Barang & Manual & Compulenred, website \\
\hline \multicolumn{3}{|l|}{ 5. Pengemasan Barang } \\
\hline Proses pengepakan barang & Gieh konimmen & Oleh operator \\
\hline Sistem Labeling barang yang akan dikirim & Lsbel khusus & Menggunikan Barcode \\
\hline \multicolumn{3}{|l|}{ 6. Pengiriman Barang ke tempat tujuan } \\
\hline Operator & Rumit & Officer \\
\hline Alat transportasi & Frailer: & Mobti Box, trudi: \\
\hline Alat komunikasi & Felepon ha & Internet \\
\hline Bakti penerimaan Barang oleh Konsumen & Form lhusus & computenzed, wetbste \\
\hline Metode pelacakan keberadaan barang & Manual & Computenired, website \\
\hline
\end{tabular}

SURYA TEKNIKA Vol. 1 No. 4, Juni 2016 : 55 - 66 


\section{Hasil dan Pembahasan}

Berdasarkan morphology chart yang telah disusun, didapatkan ada beberapa kombinasi alternatif, yaitu sekitar 2048 lebih kombinasi. Namun, tidak semua kombinasi cukup masuk akal dan dapat direalisasikan. Berikut ini merupakan alternatif solusi yang diprioritaskan, beserta kelebihan dan kekurangannya:

a. Sistem pelayanan yang berlaku saat ini

Order langsung di tangani oleh Marketing/sales melalui sistem penawaran, setelah order didapatkan dengan harga yang telah disepakati maka tahap selanjutnya adalah order dicatat dalam log book order untuk kemudian dibuatkan shipping instruction dan Pick-up Request form sebagai bukti penugasan kurir. Informasi penugasan berisikan lokasi pengambilan (konsumen), jenis barang, waktu pengambilan. Informasi penugasan diberikan secara langsung oleh bagian marketing/sales kepada petugas yang akan mengambil barang. Informasi ini juga sampaikan kepada konsumen melalui telepon atau alat komunikasi lain agar konsumen mengetahui kapan dan siapa yang akan mengambil barang.

Di tempat konsumen, petugas menerima barang dan menyerahkan bukti penerimaan barang. Kemudian dibuatkan dokumen perjalanan (way bill) dan way bill ini kemudian ditempelkan pada barang yang akan dikirim. Untuk barang yang diantar ke kantor oleh konsumen, proses ini dilakukan di kantor cabang.

Untuk pemeriksaan barang dilakukan oleh petugas yang mengambil barang dan dilakukan pemeriksaan langsung untuk kemudian hasilnya dimasukkan dalam form kondisi barang.

Untuk pengemasan barang, proses pengepakan barang biasanya dilakukan sendiri oleh konsumen, tetapi perusahaan juga menyediakan layanan pengemasan ulang jika dirasa pengemasan barang kurang rapi dan dapat menyebabkan kerusakan pada barang yang akan dikirim.

Selanjutnya, jika barang telah sampai di tempat tujuan maka ada bukti penerimaan barang oleh konsumen yang terdiri dari 2 rangkap, yaitu 1 untuk konsumen dan 1 untuk administrasi. Perusahaan akan melakukan pengecekan terhadap keberadaan barang secara manual dengan cara menghubungi operator pengiriman atau agen ditempat tujuan.

Kekurangan rancangan ini adalah kurang dapat menyelesaikan masalah ketidaktepatan waktu barang diterima oleh konsumen dan juga adanya kesulitan dalam melacak posisi barang karena sebagian besar operasi dilakukan secara manual.

b. Alternatif 1

Penerimaan order ditangani oleh petugas tersendiri atau oleh resepsionis, tidak dilakukan oleh bagian marketing seperti yang dilakukan saat ini. Penerimaan order dilakukan dengan memanfaatkan media komunikasi berupa telepon, faximile, dan internet. Ruang pelayanan dipisahkan dengan ruang resepsionis untuk lebih memberikan kenyamanan pada konsumen. Untuk selanjutnya order dicatat dalam log book order untuk kemudian dibuatkan shipping instruction dan Pick-up Request form sebagai bukti penugasan kurir.

Untuk penugasan kurir, dilakukan oleh officer/resepsionis dengan menggunakan media komunikasi telepon, hp dan internet dan bukti penugasan kurir di buatkan dalam bentuk form khusus dimana Informasi penugasan ini berisikan lokasi pengambilan barang (konsumen), jenis barang, waktu pengambilan barang.

Untuk proses pengambilan barang dilakukan oleh bagian marketing/sales sehingga tidak memerlukan petugas khusus dan alat komunikasi yang digunakan adalah internet yang terhubung ke sistem informasi konsumen. Sedangkan alat transportasi yang digunakan untuk mengambil barang adalah mobil box atau truk. Setelah barang diterima oleh bagian marketing/sales, maka tahap selanjutnya barang dibawa terlebih dahulu ke kantor dan dilakukan pengisian dan penempelan dokumen perjalanan untuk barang yang akan dikirim.

Untuk proses pemeriksaan barang dilakukan oleh bagian marketing/sales yang melakukan pengambilan barang untuk kemudian hasilnya dimasukkan dalam form kondisi barang.

Untuk proses pengemasan barang dilakukan oleh pihak perusahaan sesuai dengan karakteristik dan jenis barang yang akan dikirim. Kemudian barang yang akan dikirim diberi label khusus perusahaan.

Proses pengiriman barang ke lokasi tujuan dilakukan oleh petugas IHB dengan menggunakan alat transportasi mobil box atau truk. Alat komunikasi yang digunakan adalah internet yang terhubung dengan sistem informasi perusahaan. jika barang telah sampai di tempat tujuan maka ada bukti penerimaan barang oleh konsumen yang terdiri dari 2 rangkap, yaitu 1 untuk konsumen dan 1 untuk 
administrasi. Karena pengiriman barang ke tempat tujuan dilakukan sendiri oleh petugas IHB maka proses pelacakan barang dapat dilakukan secara langsung oleh kantor cabang dengan menghubungi petugas tersebut.

Kelebihan dari sistem ini adalah terjaminnya barang yang dikirim dari sisi keamanan dan kemudahan dalam pelacakan barang karena pengiriman barang langsung dilakukan oleh petugas IHB. Sedangkan kekurangannya adalah biaya yang dikeluarkan cukup besar terutama untuk akomodasi petugas yang ditugaskan untuk mengirim barang dan juga dari sarana transportasi yang harus dimiliki sendiri oleh perusahaan.

c. Alternatif 2

Penerimaan order ditangani oleh petugas tersendiri atau oleh resepsionis. Penerimaan order dilakukan dengan memanfaatkan media komunikasi berupa telepon, faximile, dan internet. Ruang pelayanan dipisahkan dengan ruang resepsionis untuk lebih memberikan kenyamanan pada konsumen. Untuk selanjutnya order dimasukkan kedalam sistem informasi yang terintegrasi.

Untuk penugasan kurir, dilakukan oleh officer/resepsionis dengan menggunakan media komunikasi telepon, hp dan internet dan bukti penugasan kurir tidak di buatkan dalam bentuk form khusus tapi langsung diinput pada sistem informasi yang terintegrasi dan dapat diakses secara online melalui website.

Untuk proses pengambilan barang dilakukan oleh petugas khusus dan alat komunikasi yang digunakan adalah telepon, hp dan juga internet yang terhubung ke sistem informasi terintegrasi dan dapat diakses oleh konsumen secara langsung. Sedangkan alat transportasi yang digunakan untuk mengambil barang adalah trailer, mobil box atau truk. Setelah barang diterima, maka tahap selanjutnya dilakukan pengisian dan penempelan dokumen perjalanan untuk barang yang akan dikirim di lokasi pengambilan (konsumen) sehingga barang tidak perlu dibawa terlebih dahulu ke kantor cabang.

Untuk proses pemeriksaan barang dilakukan oleh petugas yang melakukan pengambilan barang serta dilakukan pemeriksaan langsung untuk kemudian hasilnya diinput kedalam sistem komputer.

Untuk proses pengemasan barang dilakukan sendiri oleh konsumen untuk kemudian petugas pengambil barang akan memberi label barang yang akan dikirim dengan menggunakan sistem barcode dan datanya langsung masuk kedalam sistem komputer.

Proses pengiriman barang ke lokasi tujuan dilakukan oleh kurir atau agen perwakilan dengan menggunakan alat transportasi trailer, mobil box atau truk. Alat komunikasi yang digunakan adalah telepon, hp dan internet yang terhubung dengan sistem informasi perusahaan. Jika barang telah sampai di tempat tujuan, maka bukti penerimaan barang oleh konsumen langsung diinput ke dalam sistem komputer sehingga tidak memerlukan form khusus. Karena sistem operasi hampir semuanya sudah menggunakan sistem informasi yang terintegrasi, sehingga proses pelacakan barang dapat dilakukan secara langsung melalui sistem komputer yang terintegrasi dan ini memungkinkan untuk mengetahui posisi barang secara realtime dan dapat diakses secara langsung oleh konsumen melalui website.

Kelebihan rancangan ini adalah dapat mengatasi masalah ketidaktepatan waktu barang sampai di tangan konsumen dan juga kemudahan dalam pelacakan barang yang dikirim. Namun, kekurangan rancangan ini adalah besarnya modal yang harus disediakan oleh perusahaan untuk menerapkan sistem informasi yang terintegrasi dan dapat diakses secara online.

Setelah konsep rancangan dibuat, perancang kemudian memilih diantara sejumlah alternatif dengan metode pembobotan.

Prosedur Metode Pembobotan Tujuan :

1. Buat daftar tujuan rancangan

Dalam mengevaluasi adalah penting untuk memiliki sejumlah kriteria yang didasarkan pada tujuan rancangan. Tujuan ini harus mencakup faktor teknis dan ekonomis, kebutuhan konsumen, faktor keamanan, dan lain-lain. Daftar tujuan rancangan disusun dalam diagram pohon berikut : 


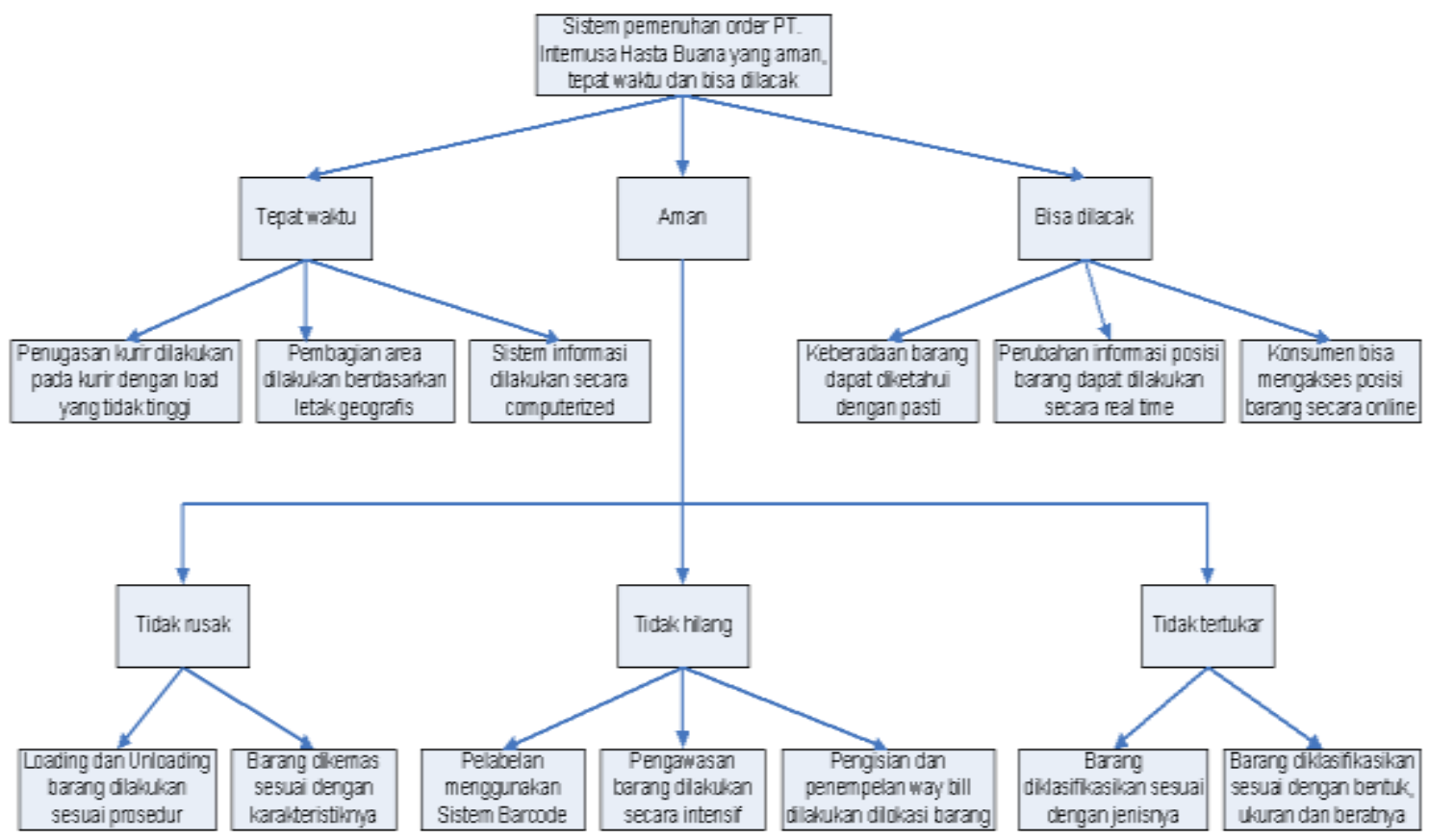

Gambar 6. Daftar Tujuan Rancangan

2. Buat daftar urutan ranking dari tujuan rancangan.

Daftar tujuan akan berisikan kebutuhan rancangan secara luas, beberapa diantaranya akan betul-betul dipertimbangkan untuk menjadi lebih penting dibandingkan yang lainnya. Proses pengurutan ranking dapat dibantu melalui pembandingan secara sistematis suatu fungsi tujuan terhadap fungsi tujuan lainnya.

Tabel 6.

Urutan Ranking Level 2

\begin{tabular}{|c|l|c|c|c|c|c|c|c|}
\hline No & Kriteria & L11 & L12 & L13 & Sum & Peringkat & Bobot & Persentase \\
\hline L11 & Tepat waktu & & 0 & 1 & 1 & 2 & 6 & 0.33 \\
\hline L12 & Aman & 1 & & 1 & 2 & 1 & 10 & 0.56 \\
\hline L13 & Bisa dilacak & 0 & 0 & & 0 & 3 & 2 & 0.11 \\
\hline
\end{tabular}

Tabel 7.

Urutan Ranking Level 3

\begin{tabular}{|c|l|c|c|c|c|c|c|c|}
\hline No & \multicolumn{1}{|c|}{ Kriteria } & L111 & L112 & L113 & Sum & Peringkat & Bobot & Persentase \\
\hline L111 & $\begin{array}{l}\text { Penugasan kurir dilakukan pada kurir } \\
\text { dengan load yang tidak tinggi }\end{array}$ & & 0 & 0 & 0 & 3 & 2 & 0.11 \\
\hline L112 & $\begin{array}{l}\text { Pembagian area dilakukan } \\
\text { berdasarkan letak geografis }\end{array}$ & 1 & & 0 & 1 & 2 & 6 & 0.33 \\
\hline L113 & $\begin{array}{l}\text { Sistem informasi dilakukan secara } \\
\text { computerized }\end{array}$ & 1 & 1 & & 2 & 1 & 10 & 0.56 \\
\hline
\end{tabular}

\begin{tabular}{|c|l|c|c|c|c|c|c|c|}
\hline No & Kriteria & L121 & L122 & L123 & Sum & Peringkat & Bobot & Persentase \\
\hline L121 & Tidak rusak & & 0 & 0 & 0 & 3 & 2 & 0.11 \\
\hline L122 & Tidak hilang & 1 & & 1 & 2 & 1 & 10 & 0.56 \\
\hline L123 & Tidak tertukar & 1 & 0 & & 1 & 2 & 6 & 0.33 \\
\hline
\end{tabular}

SURYA TEKNIKA Vol. 1 No. 4, Juni 2016 : 55-66 
ISSN: 2354-6751

\begin{tabular}{|c|l|c|c|c|c|c|c|c|}
\hline No & \multicolumn{1}{|c|}{ Kriteria } & L131 & L132 & L133 & Sum & Peringkat & Bobot & Persentase \\
\hline L131 & $\begin{array}{l}\text { Keberadaan barang dapat diketahui } \\
\text { dengan pasti }\end{array}$ & & 1 & 1 & 2 & 1 & 10 & 0.56 \\
\hline L132 & $\begin{array}{l}\text { Perubahan informasi posisi barang } \\
\text { dapat dilakukan secara real time }\end{array}$ & 0 & & 1 & 1 & 2 & 6 & 0.33 \\
\hline L133 & $\begin{array}{l}\text { Konsumen bisa mengakses posisi } \\
\text { barang secara online }\end{array}$ & 0 & 0 & & 0 & 3 & 2 & 0.11 \\
\hline
\end{tabular}

Tabel 8.

Urutan Ranking Level 4

\begin{tabular}{|c|l|c|c|c|c|c|c|}
\hline No & \multicolumn{1}{|c|}{ Kriteria } & L1211 & L1212 & Sum & Peringkat & Bobot & Persentase \\
\hline L1211 & $\begin{array}{l}\text { Loading dan Unloading barang } \\
\text { dilakukan sesuai prosedur }\end{array}$ & & 1 & 1 & 1 & 10 & 0.67 \\
\hline L1212 & $\begin{array}{l}\text { Barang dikemas sesuai dengan } \\
\text { karakteristiknya }\end{array}$ & 0 & & 0 & 2 & 5 & 0.33 \\
\hline
\end{tabular}

\begin{tabular}{|c|l|c|c|c|c|c|c|c|}
\hline No & \multicolumn{1}{|c|}{ Kriteria } & L1221 & L1222 & L1223 & Sum & Peringkat & Bobot & Persentase \\
\hline L1221 & $\begin{array}{l}\text { Pelabelan menggunakan } \\
\text { Sistem Barcode }\end{array}$ & 1 & 1 & 2 & 1 & 10 & 0.56 \\
\hline L1222 & $\begin{array}{l}\text { Pengawasan barang dilakukan } \\
\text { secara intensif }\end{array}$ & 0 & & 1 & 1 & 2 & 6 & 0.33 \\
\hline L1223 & $\begin{array}{l}\text { Pengisian dan penempelan way } \\
\text { bill dilakukan dilokasi barang }\end{array}$ & 0 & 0 & & 0 & 3 & 2 & 0.11 \\
\hline
\end{tabular}

\begin{tabular}{|c|l|c|c|c|c|c|c|}
\hline No & \multicolumn{1}{|c|}{ Kriteria } & L1231 & L1232 & Sum & Peringkat & Bobot & Persentase \\
\hline L1231 & $\begin{array}{l}\text { Barang diklasifikasikan sesuai } \\
\text { dengan jenisnya }\end{array}$ & 1 & 1 & 1 & 10 & 0.67 \\
\hline L1232 & $\begin{array}{l}\text { Barang diklasifikasikan sesuai } \\
\text { dengan bentuk, ukuran dan beratnya }\end{array}$ & 0 & & 0 & 2 & 5 & 0.33 \\
\hline
\end{tabular}
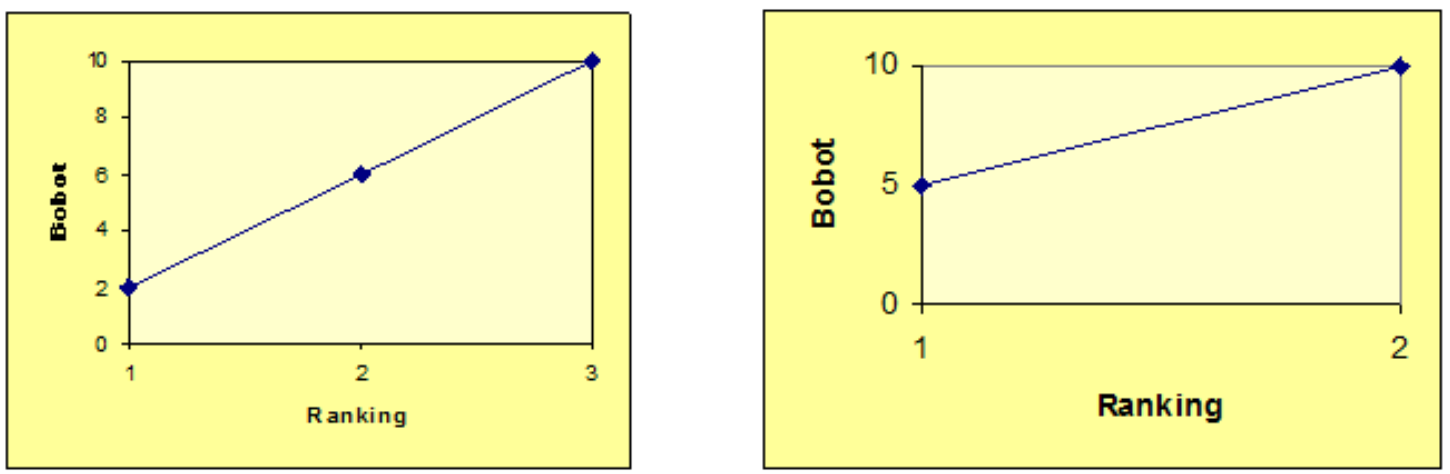

Gambar 7. Diagram Ranking - Bobot

3. Tetapkan bobot relatif masing-masing tujuan

Cara termudah adalah dengan cara menempatkan tujuan dalam posisi kepentingan relatif pada skala, misalnya 1 sampai 10 atau 1 sampai 100.

Diagram pohon bisa memberikan kemungkinan metode yang lebih bisa dipercaya dari bobot yang ditetapkan. Pada level tertinggi, keseluruhan tujuan diberikan nilai 1,0, dimana pada level di bawahnya, sub tujuan kemudian diberikan bobot relatif terhadap satu sama lain tetapi juga memiliki total nilai 1,0 . Bagaimanapun, bobot yang sebenarnya dikalkulasi sebagai fraksi dari bobot sebenarnya dari tujuan di atasnya. Penggunaan diagram pohon dalam menetapkan bobot relatif subtujuan bisa dilihat pada Gambar berikut : 


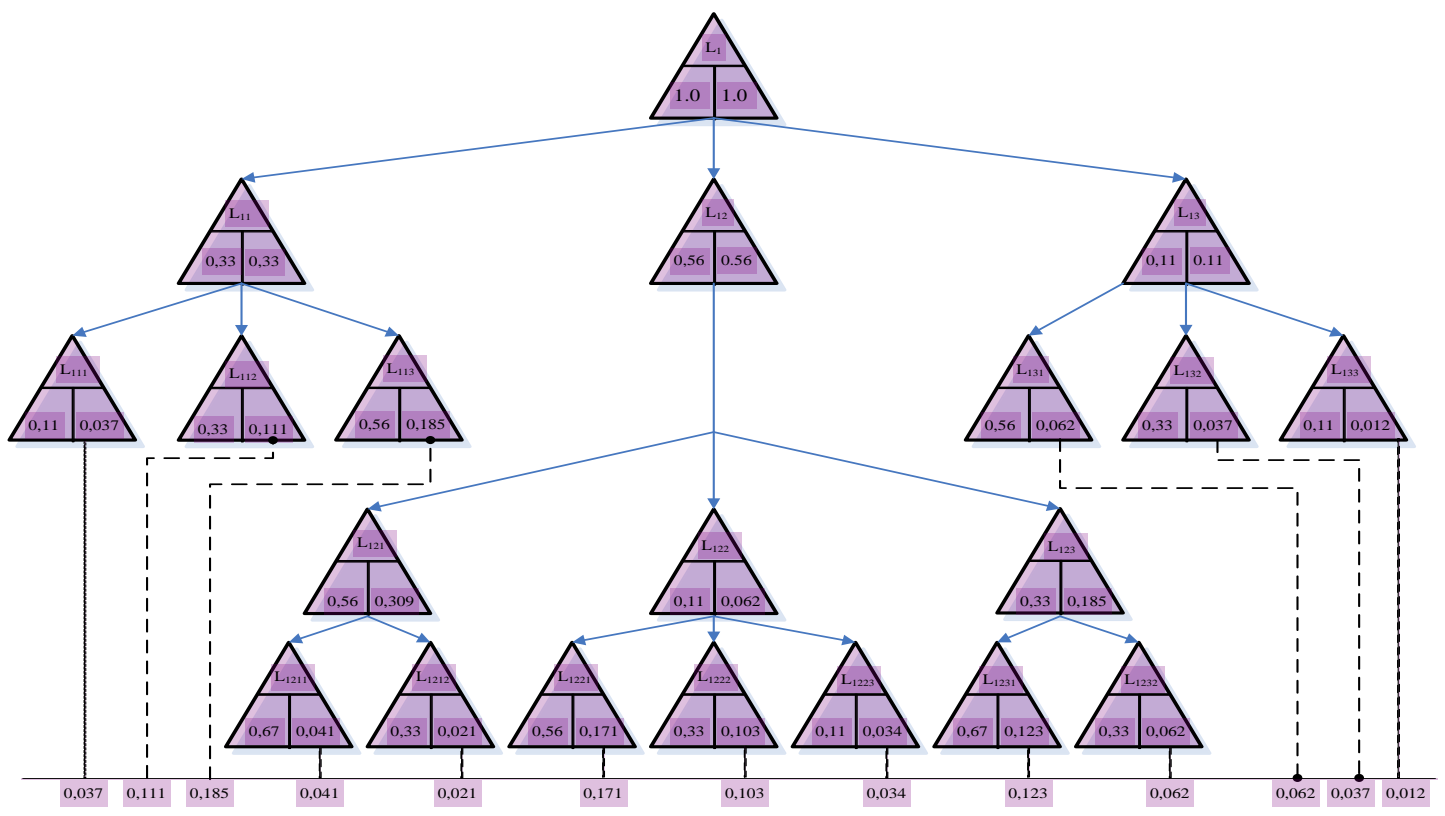

Gambar 8. Penggunaan Diagram Pohon dalam Menetapkan Bobot Relatif Sub-Tujuan

4. Tetapkan nilai performansi dari tiap tujuan Adalah penting untuk mengubah pernyataan tujuan kedalam parameter yang bisa diukur. Skala sederhana biasanya memiliki lima tingkatan yang merepresentasikan performansinya, misalnya :

1) Jauh di atas rata-rata

2) Di atas rata-rata

3) Rata-rata

4) Di bawah rata-rata

5) Jauh di bawah rata-rata
5. Kalkulasi dan bandingkan nilai relatif dari alternatif rancangan

Langkah terakhir dalam evaluasi adalah mempertimbangkan tiap alternatif rancangan dan mengkalkulasi nilai performansi masingmasing pada parameter yang ditetapkan. Partisipasi setiap anggota dalam tim rancangan sangat dianjurkan, karena beragam solusi yang berbeda bisa didapatkan dari setiap anggota.

Daftar evaluasi dari tiap alternatif rancangan bisa dilihat pada tabel berikut :

\begin{tabular}{|l|c|c|c|c|}
\hline \multicolumn{1}{|c|}{ Objective } & Wt & Sistem Saat ini & Alternatif 1 & Alternatif 2 \\
\hline Penugasan kurir dilakukan pada kurir dengan load yang tidak tinggi & 0.037 & $\mathrm{D}$ & $\mathrm{S}$ & $\mathrm{S}$ \\
\hline Pembagian area dilakukan berdasarkan letak geografis & 0.111 & $\mathrm{~A}$ & $\mathrm{~S}$ & $\mathrm{~S}$ \\
\hline Sistem informasi dilakukan secara computerized & 0.185 & $\mathrm{~T}$ & $\mathrm{~S}$ & + \\
\hline Pelabelan menggunakan Sistem Barcode & 0.171 & $\mathrm{U}$ & $\mathrm{S}$ & + \\
\hline Pengawasan barang dilakukan secara intensif & 0.103 & $\mathrm{M}$ & + & + \\
\hline Pengisian dan penempelan way bill dilakukan dilokasi barang & 0.034 & & - & - \\
\hline Loading dan Unloading barang dilakukan sesuai prosedur & 0.041 & & $\mathrm{~S}$ & $\mathrm{~S}$ \\
\hline Barang dikemas sesuai dengan karakteristiknya & 0.021 & & $\mathrm{~S}$ & $\mathrm{~S}$ \\
\hline Barang diklasifikasikan sesuai dengan jenisnya & 0.123 & & $\mathrm{~S}$ & $\mathrm{~S}$ \\
\hline Barang diklasifikasikan sesuai dengan bentuk, ukuran dan beratnya & 0.062 & & $\mathrm{~S}$ & $\mathrm{~S}$ \\
\hline Keberadaan barang dapat diketahui dengan pasti & 0.062 & & + & + \\
\hline Perubahan informasi posisi barang dapat dilakukan secara real time & 0.037 & & + & + \\
\hline Konsumen bisa mengakses posisi barang secara online & 0.012 & & $\mathrm{~S}$ & + \\
\hline Ongkos implementasi & & & - & - \\
\hline Biaya operasional & & & + & + \\
\hline Total + & & & $\mathbf{4}$ & $\mathbf{7}$ \\
\hline Total - & & & $\mathbf{2}$ \\
\hline Total S & & & $\mathbf{8}$ & $\mathbf{5}$ \\
\hline Overall Total & & $\mathbf{2}$ & $\mathbf{5}$ \\
\hline Weighted Total & & $\mathbf{0 . 1 6 7}$ & $\mathbf{0 . 5 3 6}$ \\
\hline Keteranga : & & & \\
\hline
\end{tabular}

Keterangan :

$(+)=$ better than existing

$(-)=$ worse than existing

$\mathrm{S}=$ The same as existing

Tabel 7. Evaluasi alternatif dibandingkan dengan sistem existing 


\section{Simpulan}

Dari Tabel 7 kita bisa melihat bahwa kedua alternatif rancangan memiliki konsep biaya yang sama, dimana keduanya memiliki biaya implementasi yang lebih tinggi, tetapi keduanya memiliki biaya operasional yang lebih rendah dari real system. tapi karena pada konsep rancangan ini belum dibahas secara rinci dari segi biaya implementasi dan operasional maka ukuran yang kita gunakan dalam membandingkan kedua alternatif ini hanyalah dari sisi performansi. Dari sisi performansi, Alternatif 1 memiliki total jumlah positif yang lebih sedikit dari Alternatif 2. Untuk total jumlah negatif, kedua alternatif memiliki nilai yang sama. Sedangkan untuk total jumlah yang sama dengan sistem yang berlaku, Alternatif 1 memiliki total jumlah yang lebih besar dari Alternatif 2. Sehingga secara keseluruhan maka Alternatif 2 memiliki bobot yang lebih besar dari Alternatif 1, sehingga bisa disimpulkan bahwa jika dilihat dari sisi performansi maka Alternatif 2 lebih baik daripada Alternatif 1.

\section{Daftar Pustaka}

[1] Nigel Cross. "Engineering Design Methods". Second edition. Singapore: John Wiley \& Sons. 1994.

[2] Ali Basyah Siregar. "Analisis \& Perancangan Sistem Pelayanan Logistik". Bandung: ITB. 2008.

[3] Ali Basyah Siregar. "Pemodelan Sistem". Bandung: ITB. 2007.

[4] Bowersox, Closs \& Cooper ."Supply Chain Logistics Management", Mc. Graw Hill, New York, 2002.

[5] Stock \& Lambert. "Strategic Logistics Management", Mc. Graw Hill, New York, 2001.

[6] Chopra \& Meindl: "Supply Chain Management: Strategy, Planning and Operation" Prentice Hall, New Yersery, 2001.

SURYA TEKNIKA Vol. 1 No. 4, Juni 2016 : 55-66 